Sebelas Maret Business Review Vol. 3 Issue 2, pp. 14 - 17

ISSN: 2528-0627 (print) / 2528-0635 (online)

Copyright (C) Magister Manajemen Universitas Sebelas Maret

Homepage: https://jurnal.uns.ac.id/smbr

\title{
What is the Best Strategy to Develop Creative Industry in Indonesia?
}

\author{
Muhammad Adhi Prasnowo $^{1^{*}}$ | Gusti Adriansyah ${ }^{1}$ Khoirul Hidayat ${ }^{2}$ \\ ${ }^{1}$ Department of Industrial Engineering, Universitas Maarif Latif Hasyim, Indonesia \\ ${ }^{2}$ Department of Agro-Industrial Technology Universitas Trunojoyo, Indonesia
}

\begin{abstract}
Small and Medium Enterprises (SMEs) have an important role and strategic for economic growth. This is because at the time of the economic crisis in Indonesia, SMEs are the economic sectors which have the most excellent durability. Wedoro Village in Sidoarjo city, Indonesia, is famous for the footwear creative industry especially slippers and shoes. A wide variety of slippers and shoes with different types available. Stores and outlets are widespread across the village. Wedoro region has been known as one of the predecessors of creative industries in the field of footwear. Currently the industrial centres of creative footwear is experiencing a decline in sales compared with its heyday in 2001-2006 years ago. This research aims to design a development strategy of the creative industry centre in Wedoro by using SWOT analysis and grand strategy. The results of this study indicate that the cause of the decline in sales is a flood of Chinese products, rising raw material prices, and the lack of innovation in product design. Hence, creative industry in Indonesia especially in Wedoro Village might need a guidance from the government in developing innovation in product design and marketing. It is therefore expected that the existence of a creative industry in Wedoro can grow and create occupations especially for local residents and also increase the revenue of the Sidoarjo city.
\end{abstract}

Keywords: Strategy, creative industry, footwear, Wedoro village

\section{Introduction}

According to the Ministry of Commerce of the Republic of Indonesia (2008), the creative industries are an integral part of the creative economy that focuses on the creation of goods and services by relying on the expertise, talent, and creativity as intellectual property is the hope for the Indonesian economy to rise, compete and achieve excellence in economics global. There are 14 subsectors creative industries to the attention of the government, namely; interactive games, architecture, computer services and software, research and development, advertising, printing and publishing, music, design, fashion, crafts, film, video, and photography, goods market arts, performing arts, television and radio.

In Indonesia sector, small industries are one form of alternative strategies to support the development of the economy in the long-term development in Indonesia. His role on the equity and employment opportunities for the community and contribute to foreign exchange earnings have shown that small businesses are not only active but productive (Mc Namara et al., 2017). In a broader context where small industries will be able to contribute greatly to the growth of national development (Aysan et al., 2016).

\footnotetext{
* Corresponding author at Jl. Raya Ngelom Megare No.30, Ngelom, Kec. Taman, Kabupaten Sidoarjo, Jawa Timur 61257,
} Indonesia. Email: prasnowoadhi@dosen.umaha.ac.id 
Today coaching and small business development is an important topic that should be continuously reviewed, refined and enhanced to handle more effectively. In particular, it is directed to attempt to optimize the guidance in the development of small industries (Ruiz-Jiménez and Fuentes-Fuentes, 2016).

Small and Medium Enterprises (SMEs) have an important role and strategic for the country's economic growth, both developing and developed countries (Wahyudi, 2014). At the time of the economic crisis in Indonesia, SMEs are an economic sector that has most excellent durability (Núñez-Pomar et al., 2016). The ability of small and medium enterprises need to be empowered and developed constantly to try to reduce constraints experienced by small and medium enterprises, so as to contribute more leverage to increase social welfare (Sutaryo, 2004).

The footwear industry is a promising industry in the future for the growth of the Indonesian economy because this industry is one of the industry's leading in Indonesia. After our government to promote exports in the non-oil sector, the footwear industry is one of the promising alternatives of various commodities in the phenomenon of today's economy.

Wedoro Village, District Waru, famous for the creative industry centers footwear, especially sandals and shoes. A wide variety of sandals and shoes with different types available. Stores, outlets, to home industry, are widespread across Wedoro. Wedoro region has been known as one of the predecessors of creative industries in the field of fashion, especially in the field of footwear. Currently, the industrial centers of creative footwear are experiencing a decline in sales compared with its heyday in 2001-2006 years ago. Therefore, it is necessary to design creative industry development strategy centers footwear Wedoro.

\section{Methodology}

The method used is the SWOT analysis. SWOT analysis is a tool to determine the formulation of the decision-making strategy that is based on logic to maximize strengths and opportunities, but at the same time to minimize the weaknesses and threats of the company. Stages in preparing SWOT are as follows:

a. Compile a list of opportunities and threats as well as strengths and weaknesses of the company.

b. Develop strategies SO (Strength-Opportunity) by matching internal strengths and external opportunities

c. Develop strategies WO (Weakness-Opportunity) by matching the internal weaknesses and external opportunities.

d. Develop strategies ST (strength-threat) by matching the internal strength and external threats

\section{Result and Discussion}

Wedoro Village, District Waru, famous for the creative industry centers footwear, especially sandals and shoes. A wide variety of sandals and shoes with different types, available there. Stores, outlets, to home industry, spread across Wedoro. From the data moccasins Wedoro craftsmen association can be seen in 2003, there were 571 craftsmen shoes and slippers. Wedoro region has been known as one of the predecessors of creative industries in the field of fashion, especially in the field of footwear. Formerly craft slippers in Wedoro started in 1955. At that time there were only 10 artisans who cultivate the manufacture of footwear. The results of their craft new limited marketed in the Pasar Kapasan and Pasar Tunjungan, Surabaya. In the late 1960s, when the economy is in Surabaya began to squirm and new markets such as Pasar Besar, Pasar Atom, and Pasar Kembang Jepun stand, product marketing the artisans are increasingly widespread. Along with that, the center of sandals and shoes was growing rapidly.

Currently, Wedoro region is experiencing a decline in sales of footwear as a whole when compared with its heyday in 2001-2006 years ago. The decline in performance Wedoro region alone caused more by a decrease in sales of footwear in many outlets in Wedoro. The potential development of the area-based industries and the creative economy in Wedoro region is very large and need to be optimized. In 200-2006, revenues from sales of footwear in the outlet reach about 10 to 20 million per outlet footwear. But when this happens lethargy, with turnover per day is less than 500 thousand rupiah per outlet footwear. The number of outlets was reduced drastically, from about 450 in late 2006 , being only about 50 outlets by the end of 2010. Of the expected decline, it can be calculated how much the loss of the region. The impact of 
the decline is the amount of change of use of the building, from the outlet was barefoot, into the stall / shed, even being abandoned building. Due to sluggish sales at footwear outlets in the region also led to many layoffs.

The process of making slippers in Wedoro also tend to be traditional. However, workmanship slippers can create jobs in goodly numbers. Besides being a craftsman slipper, there Wedoro residents also work as a trader of raw materials sponges, glue and tools to trade slippers to work outside the region. The slippers business is like a magnet for residents Wedoro.

Currently, Wedoro footwear entrepreneurs have to compete with China's slippers that cost much less. Problems like endless whack entrepreneurs Wedoro footwear in the village. Having felt the bitterness rising raw material prices, now, crafters slippers in Wedoro have to deal with a flood of Chinese-made slippers. Understandably, slippers made in China that have undermined the market slippers in Surabaya and surrounding areas that had been occupied crafters slippers from Wedoro. Product slippers made in this Wedoro defeated because slippers from China have much choice but valuable cheap.

Based on the data from the Ministry of Trade, the value of footwear industrial production nationwide showed an increase, but the increase is relatively small. This illustrates that the selling price is not significant increase mainly to the domestic market due to competition with imported products at a low price as well as people's purchasing power is still lacking.

Exports of footwear products in 2009 worth USD 1,599 billion, while exports in 2010 valued at USD 1,428 billion, or 11.97 percent experienced enhancers. On the other hand, based on Indonesia Startistical Bureau data, imports of footwear products have been increased. Imports in 2009 worth USD 59,285 million and in 2010 to USD 71,105 million or an increase of approximately $19.93 \%$. But obviously, it appears that the domestic market is flooded with imported products at bargain prices that distort national footwear industrial markets. footwear industry, including priorities, are developed in accordance with the National Medium-Term Development Plan (Presidential Decree No. 7/2005) with the consideration of potential owned as follows.

a. There are approximately 390 companies in footwear industry with a production capacity of 1.14 billion pairs per year, in addition to the 84 centers Small industrial footwear.

b. The availability of human resources easies for students to become skilled workers at competitive wages.

c. The development of synthetic leather industry/quality synthetic either as raw material for the footwear industry non-leather,

d. Growth of supporting industries and components such as industry last / reference, glues / adhesives, textiles, shoelaces, sol (inside and outside).

e. As one of the footwear manufacturers the potential in the world.

In 1996 the export value of footwear products nationwide approximately USD 2.2 billion was ranked third in the world. The economic crisis that hit Indonesia on the performance of the industry, particularly exports, so that in 2006, Indonesia's position slipped to 10 below China and Vietnam, with an export value of about USD 1.6 billion. In 2000 in the reform era, the footwear industry has improved. If the first export activities into the primary, then in the domestic demand footstool. APRISINDO (Indonesian Footwear Association) and the government participated work together to help this industry to be able to grow even more. One form of such support is to hold the program "Back to School" which makes the response to market demand for shoes, sandals, bags, stationery, and other increases dramatically during the holidays for the preparation of students entering a new school year. The result is the growth of the footwear industry from year to year has increased. Data from the ministry of trade Indonesia footwear sales in 2011 reached IDR 24 trillion to IDR 25 trillion and is expected to continue to grow.

Free trade is the economic activity that is carried out in the absence of artificial barriers (barriers applied by the government) in trade between individuals and companies -the company that is in a different country. In the absence of constraints applied by the government in implementing the trade, of course, there is the freedom of the rules, manner, and type of goods sold. Then, comes the trade competition tight either between individuals or companies located in different countries that we are familiar with the terms of export and import or process the sales and purchases made between States 
Product innovation is a combination of the various processes that interplay between the one another invitation. Therefore, innovation is not a concept of a new idea, a new invention nor is a development of a new development, but innovation is a combination of all these processes. The scope of the product innovations that include:

a. Economic innovation

Dealing with purchasing power so that the user needs to find some way of purchase that does not charge users. By way of purchase of mortgage allows the buyer can have the products according to the needs that ability.

b. Innovations in technology

Dealing with objects of a technical nature that can change and improve a product or goods that are outdated. So the way redesigns or through new technologies can be improved productivity and cost savings.

c. Social Innovation

Dealing with culture and so that the user can change the value of customer satisfaction, then by way of imitation, import and tap innovation in engineering can deliver success.

With modern technology today, can do product innovation so as to meet market demand. Product innovation, for example by following the model favored by consumers. On the production side, the rapid technological development strongly supports the performance improvement of production processes. The development of appropriate technologies and the use of more modern equipment allows the design of the production process more effective and efficient.

In fact, the footwear industry can be classified into small, medium, and large industry. The footwear industry has been famous since ancient Wedoro. Industries that actually originates from this craft increasingly show a strong increase and demand is high. Commodities Wedoro footwear industry is the mainstay industry of Sidoarjo city, the quality is unquestionable, while production is a variety of designs that can adapt to the tastes of consumers. for marketing in addition to meet the needs of the local communities themselves also marketed to other regions and even exported abroad.

\section{Conclusion}

The conclusion of this study indicates that the cause of the decline of Wedoro creative industry specialized on footwear is a flood of Chinese products, rising raw material prices, and the lack of innovation in product design. The guidance from the government of Indonesia is believed can be a main solution for this problem. The government could assist the industry to innovate in product design product design and marketing. Therefore, the existence of a creative industry center Wedoro can grow and create jobs for local residents as well as increasing revenue of Sidoarjo city.

\section{References}

Aysan, A.F., Disli, M., Ng, A. and Ozturk, H. (2016), "Is small the new big ? Islamic banking for SMEs in Turkey”, Economic Modelling, Elsevier B.V., Vol. 54 No. October 2015, pp. 187-194.

Indonesia, D.P.R. (2008), Pengembangan Ekonomi Kreatif Indonesia 2025.

Mc Namara, A., Murro, P. and O’Donohoe, S. (2017), “Countries lending infrastructure and capital structure determination: The case of European SMEs”, Journal of Corporate Finance, Elsevier B.V., Vol. 43, pp. 122-138.

Núñez-Pomar, J., Prado-Gascó, V., Añó Sanz, V., Crespo Hervás, J. and Calabuig Moreno, F. (2016), "Does size matter? Entrepreneurial orientation and performance in Spanish sports firms”, Journal of Business Research, Elsevier Inc., Vol. 69 No. 11, pp. 5336-5341.

Ruiz-Jiménez, J.M. and Fuentes-Fuentes, M. del M. (2016), “Management capabilities, innovation, and gender diversity in the top management team: An empirical analysis in technology-based SMEs”, BRQ Business Research Quarterly, Elsevier, Vol. 19 No. 2, pp. 107-121.

Sutaryo, S. (2004), "Pengaruh Karakteristik Inovasi terhadap Adopsi Tekonologi Internet oleh UKM”, Jurnal Ekonomi Dan Keuangan, Vol. 2 No. 2 (Juni), p. 290.

Wahyudi, I. (2014), "Commitment and trust in achieving financial goals of strategic alliance", International Journal of Islamic and Middle Eastern Finance and Management, Vol. 7 No. 4, pp. 421-442. 